\title{
A Critic to Darwinian Theory on Resources Scarcity on the Basis of Quranic Verses
}

\author{
Ramezan Mhadavi Azadboni \\ Associate Prof, Department of Islamic Philosophy and Theology, University of Mazandaran, Iran \\ r.mahdavi@umz.ac.ir
}

http://dx.doi.org/10.18415/ijmmu.v8i9.2860

\begin{abstract}
One of the important components in the theory of the evolution of species is the idea of natural selection. The question is, are the assumptions of the subject in the idea of natural selection compatible with the religious conception of nature and the world around? In this study, the author will discover on the base of Quranic verses that how the theory of biological resource scarcity as one of the basic assumptions in the idea of natural selection conflicts with the Qur'anic interpretation regarding nature. If we can show the lack of credibility and inaccuracy of the idea of the biological resources scarcity and the inappropriateness of biological resources with the needs of the creatures-as one of the assumptions underlying evolutionary theory-in this case, an important step has been to distort the above-mentioned theorem. In the Holy Qur'an, traits such as selfishness are often warned that are considered as the basis of excesses leads to poverty and shortages. Quraanic promises according to which righteous individuals will govern on earth, on the one hand, and the divine promise of securing the living of the beings on the other hand effectively challenges the idea of natural selection.
\end{abstract}

Keywords: Evolution; Resource Scarcity; Qurann, Darwin

\section{Introduction and the Question}

It can be argued that the most intense and flaming conflicts between science and religion in the 19 th century were formed around the issue of the origin of life and creation. The consequences of the theory of the evolution as a scientific response to the origin of life make this theory the focus of attention. Darwin's role can also be seen in the 19th century, like Newton's role in the 17th century (Ian Bard, 13, p.). Discussion and reflection on the theory of evolution is necessary in this regard, which provides a perspective on humankind that affects many of humanity's fundamental problems and problems. Specifically, the type and manner in which we consider mankind has a direct or indirect impact on other components of our worldview. The theory of atheistic evolution negates the existence of God; therefore, it must present other source for morality other than religion. The famous 18th century poet William Pali in the West and Kierkegaard are the thinkers who defend the theory of ethics that is based on religion. The famous Russian writer Dostoyevsky also acknowledges the importance of the ethical role of religion according to whom 
without God, morality will not exist, and without God anything action is allowed. (Dostoyevsky, 1950, p.283)

Also, the socio-political impact of the theory of evolution is negligible. The theory of evolution in this regard is a turning point in human history, especially in western culture. Willdurante believes that the name of Darwin and the theory of evolution in the Western world are a turning point in culture (Durante, 1931, p.22) The theory of evolution draws the social values of society to the point where it is a surprise to help one's weak friend, and this point was acknowledged by Darwin. According to him "Helping the weak means slowing down the process of eliminating the poor, and this is very destructive to the human race" (Darwin, 1902.p.180)

The consequences of the theory of evolution, religiously, morally, and so forth, are in a way that provokes theologians to present a hostile reaction against it. Many of the evolutionists are obviously aware of the implications. Huxley was one of the contemporary and keen advocates of the theory of evolution, and admitted that the aforementioned theory makes ethics and morality as a futile event (Huxley, 1986, p.83) In addition, many atheists and dissidents of religion and ethics have adopted the theory of evolution of species as the most important means to justify their claims (Provine, 1988, p. 28), and many of the political and social movements or are rooted in the theory of evolution, or are under its effect. (Holme, 1959, p. 80) Despite the implications of this theory and the hostility against it, some theologians tried in a variety of ways to reconcile the theory of evolution and the theory of creation in order to dispel the contradiction between science and religion. This group of thinkers defended the idea of divine evolution for this purpose. The view that its defenders and representatives argue the correct process of the creation of beings, which is supported by scientific evidence as well as religious texts, is a gradual evolution, and God is the guiding such process. The author in this study is trying to demonstrate the impossibility of reconciling the theory of evolution with theism. The aforementioned view-the impossibility of compromise-is a reflection of the deep understanding of the fundamental assumptions of the theory of evolution. For this purpose, first, the theory of the evolution of species is outlined in a general exposition. It will be shown that the idea of the lack of biological resources has played a fundamental role in shaping the idea of natural selection as an essential component of the theory of evolution in the mind of Darwin. If we can show the lack of credibility and inaccuracy of the idea of a shortage of biological resources and the inappropriateness of biological resources with the needs of beings-as one of the implications of the theory of evolution-then an important step has been taken to distort the aforementioned theory. If the idea of natural selection as the child of the idea of a lack of biological resources is faced with an insoluble challenge, then the opportunity and the possibility of a reasonable defense of the theory of evolution, whose validity is due to the validity of the idea, is lost.

\section{The Theory of the Evolution of Its Essential Elements}

History of the theory of evolution was not limited to Darwin in the 19th century, but years ago before Darwin in Greece, the theory of evolution represented. It is said that Democritus and Tales believed in evolution (cited by Moore, 1979, p.5o2). Aristotle also considered the evolution as the first philosopher who systematically formulated biology. Of course, it is clear that the interpretation of the evolution of the Greek thinkers is different from what was presented by Darwin in the 19th century. According to Aristotle, nature is purposeful. In the book of Physics, he says: "If the artifacts are purposeful, the natural affairs are the same. For example, the plant makes the leaf a shelter for fruit (Aristotle, 1957, p. 173). According to Aristotle's view, nature is systematically categorized and designed. Your existing classification is from the weak to the higher order.

The Aristotelian image of nature consists of two fundamental components, in which both components are denied in Darwin's theory: 
A) The nature is regular and purposeful.

B) The nature is constant and irreversible.

The meaning of these two components in the Aristotelian image of nature is that each class and type is constant. Aristotle also, in order to pave the way for learning scientific knowledge as a necessary step before addressing ontology, first sets out logic and makes many innovations in the science of logic. Among them is the question of classifying organisms. In the classification of beings, Aristotle considered their characteristics and classified those beings that were intrinsically common in certain attributes, under the particular title of kind or "species". It is possible that each creature will lose some of its features and change and evolve but cannot escape the class in which it is located. Change and evolution in creatures means that it is impossible to leave a type to another, according to Aristotle, and the creatures only exhibit in-kind changes. Therefore, the word "type" or species refers to a certain class of organisms, which is why they are placed in a particular class on the basis of their immutable characteristics (Stumpf, p.84). In the 19th century, Charles Darwin described the evolutionary theory differently from that of the ancestors. In the perspective of the ancients, evolution was not a blind and uncontrolled flow, but with Darwin, evolutionism is direct connection with materialism. Darwin, however, clearly did not express the materialist nature of his theory. According to Darwinian theory of evolution, organisms in their current form and complexity are the result of an evolutionary process and are in fact the evolved form of the preceding types, and it is not so that the types have the first day and are in the same way created by the Creator. In his experimental defense of Darwin's theory of evolution, Darwin studied the domestic animals, such as dogs, in detail. It has been seen that the educator chooses the desired changes that he wants to retain, and after several generations of selection, of all those selective variations, there are new types that he did not already exist (Ian Barbour, 1361, p. 107) Thus, Darwin's answer to one of the fundamental questions about human life: the origin of the creation was the presentation of the theory of evolution, according to which there are creatures, including humans, because they were led to their evolutionary movement. Darwin, for the sake of this theory, first saw some changes among beings. Particularly during the Voyage of the Beagle, many samples attracted his opinion for further study. To explain them, he calls the concept of competition. According to him, the concept of competition in the theory of evolution is a type of fundamental concept. Competition and struggle are two phenomena in the world. On the one hand, organisms have intrinsic tendency to proliferation and reproduction. The inherent nature of their beings is their proliferation. On the other hand, the resources of the environment are limited. Environmental constraints and inequalities of environmental resources with the biological need of organisms are the source of a biological conflict. In such a battle and the biodiversity, nature and environment are decisive. In such a situation, Darwin expresses the idea of natural selection as another essential component of evolutionary theory. Natural selection means that the decisive factor to determine the winner in the biological conflict, is set through the environment. The environment only gives the creatures a chance to display their ability to adapt to the environment. The result of the attempt of the creatures to adapt to the environment is the occurrence of gradual changes that lead to the emergence of new types in a long-term gradual process. Thus, these three components: the observation of variations in types, the idea of competition, and the idea of natural selection, are the basic elements of the theory of evolution.

\section{Natural Selection and Biological Resources}

As stated, one of the pillars of the theory of evolution is the idea of natural selection. Darwin, by means of this idea, was able to interpret the occurrence of changes in the types. But how can Darwin think and defend the idea? The idea is based on another assumption that plays the role of the underlying principle in evolution theory. Darwin's principle is owed to Thomas Malthus. When Darwin was studying Malthus's article, he adapted the idea of a competition caused by a shortage of biological resources. (Darwin, 1958, p. 12). Thus, Darwin was influenced by Malthus in his theory of evolution. Malthus's view of the relationship between population and biological resources was the basis of the formation of Darwin's mind in relation to nature and the world. Nature has been conceived in Darwin in a particular way. From Darwin's 
point of view, nature plays a major role in creating battles. According to the theory of the evolution, the present forms of the creatures and the complexities in which they are, is the result of the struggle for survival and, not God created them at a particular time. Darwin himself, in the early days of his youth, was impressed by William Pali, a prominent 18th century theologian, that the wonders of a variety of products are the direct interference of God in creation. But in evolution theory, the wonders in the biological structure of plant and animal types, including human beings, are not due to the intervention of God, but the result of the struggle for survival. According to Darwin, the struggle for survival has its own dual effect. First, the limitations of biological resources in the environment on the one hand, and the second, the desire to proliferate in the beings, on the other hand, make it possible for the creatures to survive, and in this campaign, those creatures are victorious that adapt themselves environmentally to conform. The result is adaptation to the environment of acceptance of change. These changes gradually become part of their traits and are passed on to subsequent generations through inheritance, and by this changes new types are formed with new forms. The result is that the environment is like a table that is not able to suit everyone and thus becomes a battlefield for them and the victory is for those who have the power to adapt to the environment. Darwin's image of the environment emphasizes the constraint that is the source of the struggle for survival. Struggle and war as the motto and the law of victory are completely clear. Selfishness, as the motto and main words in the struggle for survival, is the secret of victory. With such a rule and slogan in life how can one speak of morality. Many, even their evolutionists, acknowledged the incompatibility between morality and evolution theory, including Huxley who developed the theory of evolution and considered it as antithesis for ethics. (Huxley, 1986, p.83) Such a conflict between morality and evolution was also a clear matter for German philosopher Nietzsche. In his view, the theory of evolution completely substitutes the moral values (quoted by Ian Barbour, 1367, p. 137). The root of the conflict evolutionary theory with ethics is related to the type of image that is expressed about the environment by him. An image of that environment's limitations is the source of controversy, and struggle and the main law of victory in such battle then is being selfishness. In other words, if the idea of a shortage of biological resources is one of the pillars of the theory of evolution, it will become clear that the most fundamental moral principle in human life will be the principle of selfishness. If the idea of the lack of biological resources in this theory is the basis of such an argument, then human efforts to conform to such behaviors will be inevitable. Because it is outside the power of man to act contrary to such a law and principle. However, in ethics, there is a law against such a law, from which it is construed as a Golden Rule. Based on this ethical principle, human altruistic behaviors have unquestionable moral value. The acceptance of the theory of evolution of the species is due to the idea that there is a shortage of biological resources, and this idea, in its turn, confirms the principle of selfishness as the rule determining the behavior of humans. In its essence, it conflicts with the golden rule, and will change it as the Iron Rule. According to the golden rule, what human beings like themselves should also be the same for others. In the recommendation of Imam Ali (a) to his dear child, Imam Hassan (AS), the law is emphasized:

Oh My son put yourself as a scale about what is related between you and others. Then like for other what you like for yourself and dislike for yourself what you dislike by other. (Nahj al-Balaghah, 270, (labib Beyzoun, P. 751)

Based on this advice from Imam Ali, the moral law governing people`s behaviors are not law of force or power while in the theory of evolution, force and power, are considered as inescapable biological law for human conducts. Evolutionary theory permits and legitimates any selfish based conducts and in fact it changes the golden rule to the Irony law according to which any human being is allowed to act against other before they do anything against you. (Holmes, 1939, p.12)

One of the concerns of the theists in the face of evolutionary theory is that moral values are undermined by it. According to the author, this ethical consequence of the theory of evolution is one of the underlying problems of the theory, and it is rooted in the kind of look and perspective adapted by Darwin toward environment, and through such a picture the conditions for the adoption of selfishness are provided as the first law of life. If Darwin's view of the environment is correct, then the ethical conclusion mentioned 
above would be correct. Since this ethical consequence is the result of one of the effective foundations for the development of the theory of evolution, namely the idea of lack of biological resources, it is necessary to look at Darwinian image regarding nature and the environment to be criticized.

\section{Biological and Environmental Resources in the Mirror of the Divine Verses}

In contrast to Darwin's image of nature and biological resources, the religious and Qur'anic image is completely different. From the point of view of Quranic verses, the environment is rich in resources and biological necessities and is not considered to be a direct contributor to biological conflict due to the shortage of biological resources required by the beings. Religious perception of the world in terms of biological resources is a perception based on abundance and deficiencies are caused by malicious actions. As an example in the Bible, Genesis is said that all the essentials of life in the world are provided (Holy Bible, Genesis 1: 29-30).

The study of Qur'anic verses shows that conflicts are not caused by the limits of the environment, and the lack of biological resources is not the description of the biological world. The result of thinking in verses of the Holy Qur'an indicates the human and ethical roots of the quarrels. The idea of a shortage of human resources is not biological rather it is rooted in human conducts and desires. The pattern of animal life and behaviors is instinct. However, according to the Holy Qur'an, the biological requirements of any animal are provided, and according to such underlying ground the idea- resources scarcity - can be ruled out even in the case of animals. But human beings, according to the Qur'anic view, are supposed to be excelled as moral agents, with the power of will and freedom, then the environment should be a suitable ground for realizing that purpose. If the idea of a lack of biological resources is correct, then the realization of the moral purpose in human life is unlikely to be conceived. It can be interpreted as a conflict between creation and decree. Allah Almighty has designed a major goal in the creation of man at the stage of creation and through the decree and guidance of the prophets, man can move towards that goal in his own life with application of the power of reason. Referring to the verses of the Holy Quran clearly indicates that the moral development in human life is one of the main interpretations in the expression of this purpose. (Surah Juma 2 and Surah Baqarah Ayah 128) If a person is to be exalted by the will of the Lord of the universe as the caliph of the Lord (verse 29) and the moral being, then the conditions and requirements necessary to achieve this goal must be provided. The suitability of human biological conditions is also one of these requirements. If the characteristics of the environment and the conditions of the human being are manifestations of deficiency, then the system designed by Allah will reveal the contradiction that between the purpose designed to create humanity and the conditions required to achieve that goal. But the author believes that recourse to the Holy Quran clearly denies this. The environment, though it may be the battlefield of humans, is not the source of battle. Among them: in Sura Asra, verse 31, it says: "Do not kill your children from hunger, we will provide your livelihood and they will be provided of it.

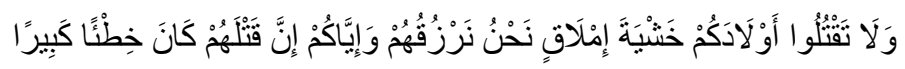

According to this verse, that fear of poverty and hunger lacks the foundation. Also in Sura Hood, 6 Holy Qur'an states: "There is no living creature unless its food is given by God ..."

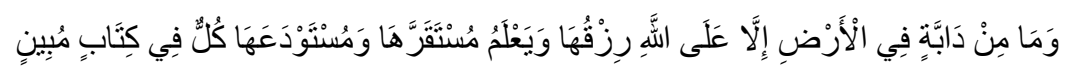

According to this verse, the environment is not like a tiny table for creatures, but the food of every living creature is provided in it. In this verse, the false idea of the lack of biological resources is not rejected only about human beings, but also of any living creature.

Of course, in the world of beings, even among humans, we can see competition for biological resources, but this does not mean that the emergence of organisms was based on this factor. Particularly the struggle between humans can be attributed to other factors other than the shortage of biological resources. 
Also, the Quranic phrase " دَابَّة " (Daabbah ) implies any living creature. Therefore, the theory of shortage of biological resources is not credible even for animals based on Qur'anic teachings. In the Holy Qur'an, while human misconduct is an important factor in the occurrence of deficiencies, the excessive behavior of human beings is also the source of conflict, and otherwise the environment is described as rich and sufficient in biological resources for the life of beings.

"Corruption and ruin in the sea and inland were manifested by human behavior":( verse 30/sign 41)

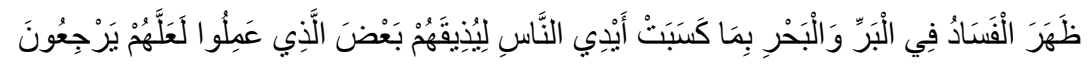

Based on the teachings mentioned in the Holy Qur'an, it is clear that the idea of lack of biological resources is inappropriate for humans and cannot therefore be taken as a pillar of evolutionary theory. Consequently, the theory of evolution is not capable of providing a convincing explanation of how human beings are created. How can one expect this theory to succeed in answering its original question about the creation of the beings? If this theory, on the one hand, relying on the idea of a lack of biological resources, seeks to explain how the beings are created, and on the other hand, the falsehood this idea admitted in the Holy Qur'an. If this is the case the theory fails in explaining the existence of creatures.

Moral vices such as hobbies, excitement, lack of saving, and contentment are an effective factor in creating constraints and quarrels. Therefore, from the Qur'anic perspective, the environment is not the origin of the struggle for survival because the environment is sufficiently the treasury of living beings, and also the wars and hostilities among humans are the result of their evil behavior. According to the verses of the Holy Qur'an, if a person acts on the basis of piety, the doors of the earth and the temple will open for their reception. In the face of sin and bad man's behavior, he has an effective role in the advent of suffering and hardship:

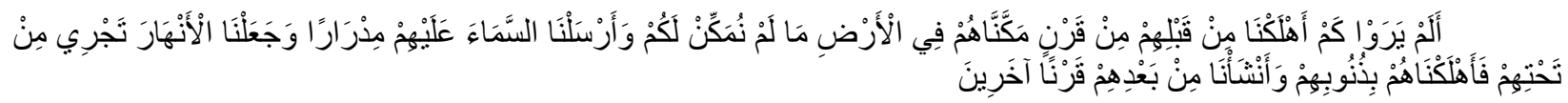

The Holy Qur'an has repeatedly emphasized the excesses and supremacy of human beings, often expressed by concepts such as ( كبر ) al-kobr-arrogance, etc., is the source of hostility and conflict. It is clear that to deviate from the path of piety and ethical weakness make a situation or character as a phenomenon that is often referred to in the Quranic verses as "corruption":

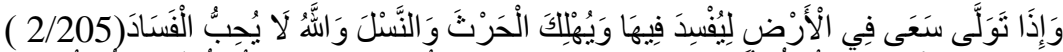

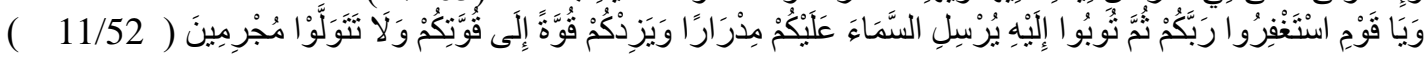

According to these verses and such a description, how can the theory of evolution, even in the divine form, be the answer to the question of the origin of the creation of man or beings? In the theory of evolution, the environment is an effective factor in the occurrence of a biological conflict, while the result of reflection in the verses above shows the direct role of humans in the occurrence of battles between humans.

\section{Concluding Remarks}

Reflection in the current context of the contemporary world can help identify the factors that threaten the life of beings, including humans. Today's world, which has actually turned into a world village, but also a glass tower, has clearly seen the deaths of humans due to hunger. The origin of these disastrous events around the world is not limited resources in term of resource scarcity as pillar in Darwin`s evolutionary theory. The environment is full of God-given blessings. Also, the human disability in terms of technology in transferring resources to each other is not the cause of the incidents. Because in the global village and glass tower, not only humans are in a position to help each other, they can help each other if 
they want to. The problem is rooted in the will those who are in the power and use the recourses as means for their goals not for the poor. It was once believed that mankind, equipped with technology and scientific ability, would be able to erect a promised paradise early on the earth and destroy the root of suffering by the help of science (Ian Barbo, 1367 p. 79). The realization of this may not be beyond reality, but the factors that prevent the achievement of such an aspiration and wish are not the environment, but the moral weakness of mankind is its origin.

\section{References}

Holly Quraan.

Holly Bible.

Aristotle, The Physics, London: William Heineman Ltd. 1975.

Aulie, R. P. The Doctrine of Special Creation, J. Amer. Scientific, (1975), 27: 8-11.

Darwin, Charles, The Decent of Man, (1902), London: P. F. Collier and Son.

Dawking, Richard, the Selfish Gene, 1989.

Dayrant, Will, Great Men of Literature, (1931) Garden City, NY: Doubleday.

Dostoyevsky, Trans by C. Garnet, (1950), New York: Random House.

Gold, Stephen, Ever Since Darwin, (1977) London.

Holme, S. J. Evolution, (1959), Toronto, Canada: International Christian Crusade.

Holme, S. J. Science, (1939), Toronto, Canada international Christian Crusade.

Huxley, Thomas, Evolution and Ethics (1986), New York.

Lipson,H. S. A Physicist Looks at Evolution, in Physic Bulletin, (1980), 31, May.

Provine, William, Evolution and the Foundation of Ethics, MBL Science 3, 1988.

Soren Kierkegaard, fear and trembling, (1954), New York: Doubledday, pp. 70, 91.

Stumpf, Enoch Samuel, Socrates to Sartre, McGraw-Hill, Inc.

Tompson, Bert, The Scientific Case for Creation, (1986), Apologetic Press.

William, paley, works(ed)D. S. wayland (1937) vol, 1.

\section{Non- English References}

Ian Barbour, Science and Religion, Translation to Baha'uddin Khoramshahi, Second Edition, 1995, Academic Publishing Center.

Tabatabai, Allameh Mohammad Hussein, Al-Mizan commentary, J 16. 
Nebula, Yadollah, Human Creation, 13th edition, 1375, Public Joint Stock Company.

Nahj al-Balaghah, Lobib Beyzoun, 1408, Maktabah al-A'lam al-Islami, al-tabaa al-Saessiyah.

\section{Copyrights}

Copyright for this article is retained by the author(s), with first publication rights granted to the journal.

This is an open-access article distributed under the terms and conditions of the Creative Commons Attribution license (http://creativecommons.org/licenses/by/4.0/). 